\title{
PLACE, RELATIONSHIPS, AND COMMUNITY- CONTROLLED CAPITAL: ON ECOSYSTEM-BASED INNOVATION TOWARDS AN EQUITABLE COMPETITIVE ADVANTAGES DISTRIBUTION, THE BOSTON UJIMA PROJECT CASE
}

\author{
C. BEVILACQUA \& Y. OU \\ CludsLab PAU Department. Università Mediterranea di Reggio Calabria, Reggio Calabria, Italy.
}

\begin{abstract}
The paper proposes that the issue related to an emerging inequality in advanced democracies due to the knowledge-based economy is partially argued in literature. Despite the political approaches traditionally grounded on the opposition of equality-oriented capitalism to efficiency-oriented capitalism, the shocks of technology produce results that tend to skew towards income and wealth polarization. The ongoing results of the new technologically driven economy reveal an increasing need for alternative ways to ensure an equitable distribution of the competitive advantages among the whole population. To strive against this polarization, the authors illustrated an example of multi-sectoral communitybased institution, which can collaborate to construct economic democracy by empowering the civil society with the decision-making power in the economic sphere. The study stands out from the existing empirical studies by taking the Boston Ujima Project (BUP) as an analytical framework with the aim of looking at the extent to which a place-based and multi-stakeholder innovation ecosystem promotes economic democratization and helps to address socioeconomic inequality. The paper defines an analytical tool based on a comparison of literature review and the organizational structure of BUP. The literature review allows to look into the economic impact of social innovation, focusing on the economic democratization process and 'system thinking' embedded in social innovation. Then, the BUP grounded in the systematization of literature review is described as an innovation ecosystem based on the multi-stakeholder collaborative mechanism, a novel ecosystem-based innovation approach to address socioeconomic inequality. It is found that by incorporating 'ecosystem' into social innovation process, the BUP has created a holistic, integrated approach that joins place, capital and relationships to address socioeconomic inequality.

Keywords: Boston Ujima Project, economic democratization, ecosystem-based innovation, innovation, socioeconomic inequality.
\end{abstract}

\section{INTRODUCTION}

Although a new economy driven by ICTs has been expected to fundamentally change the nature of capitalist economy, it has failed to cope with business cycle, inflation and unemployment [1]. This has led to an economic growth hammered by innovation and technological change not equitably distributed [2], over increasing spatial inequalities at 'all geographical scales, from the neighbourhood to the international system' [3] (p. 13). Due to this inequitable distribution, the competitive advantages generated cannot serve as an effective, endurable solution to socioeconomic inequalities. In this sense, the alleviation of socioeconomic inequalities can be promoted through a more equitable distribution of competitive advantages. This is nothing simple, as whatever evolving forms it may take, capitalism has legitimized an economic development pattern that prioritizes economic efficiency, economic growth and economic values [4], [5], while being 'geographically uneven, socially unjust, and ecologically dangerous' [6] (p. 149). Neoliberal economic principles have led to a concentration of wealth, power and economic activities, by legitimizing policies that consolidate 
capitalist class power. Meanwhile these principles assert that neoliberal values like individual freedom, liberty, privatization, free market and free trade always bring about positive outcomes [7]. Consequently, the new economy has consolidated global economic hierarchy rather than democratizing ownership [8].

In the light of competitive and comparative advantages coming from cluster spatialization and urban transformation [9], social innovation is often delegated to a sort of counterbalanced measure to cope a non-inclusive process of global growth. The case of Boston Ujima Project (BUP) offers another face of innovation ecosystem, namely an ecosystem based on social innovation. The research, with a mixed-methods approach that combines literature review, quantitative and qualitative methods, proposes an ecosystem-based innovation approach to socioeconomic inequality by reinforcing the role of social innovation as catalyst for economic growth integrated with income distribution. The theoretical base is a conceptualization of economic democracy within innovation process to promote a more equitable distribution of competitive advantages.

The paper first provides a theoretical outline of how economic democracy and social innovation may work together to promote a more equitable distribution of competitive advantages arising from knowledge economy. Then, the BUP case study is analyzed according to the methodological approach and objectives defined by the conceptualization of economic democracy in innovation process. Finally, a new approach to economic democracy built on the BUP case is discussed and proposed as a place-based and multi-stakeholder innovation ecosystem for equitable distribution of competitive advantages.

\section{ECONOMY DEMOCRACY AND INNOVATION: A THEORETICAL SYNTHESIS}

It has long been acknowledged that escalating socioeconomic inequality threatens democratic ideals [10,11] and has a negative impact on growth [12-17]. Academically, scholars have argued various ways to trigger systemic change and thereby achieve socioeconomic equality. For example, Ghista [35] proposes a neo-socioeconomic political system, which combines collective capitalism, socioeconomic democracy and professional civilian governance to realize the full potential of human development. Hahnel [20] argues for an empowerment-based approach to social problems by decentralizing the decision-making. Such a problem-solving process can not only transform the civil society into active actors, but trigger social innovation, the aim of which is right civil empowerment [27]. Some scholars also stress the importance of institutions in driving systemic innovation and local development [25], [36], [37], which as 'mechanisms for social cooperation' can concretize social aspirations into realities and promote civil and political participation. Politically, many welfare states in Europe have experimented with equality-oriented capitalism in opposition to the classic efficiency-oriented capitalism. Their strategies of socioeconomic alleviation are mainly based on social investment to improve redistribution so that disadvantaged population can share the benefits of growth [31]. It is true that low socioeconomic inequality has been achieved; however, this comes at the cost of high and growing fiscal burden due to tax revenue constraints [32]. Alperovitz and others [23], therefore, attach great importance to 'system', which means that systemic problems demand systemic solutions. Porter [24] also argues that urban problems cannot be cured by simply increasing social investment. He criticizes social model-based programs aiming more directly at economic development for being fragmented and ineffective. Without an overall strategy, they have isolated the areas under intervention from their adjacent economy and social context. In consequence, such programs have produced isolated businesses poorly equipped to remedy complex social problems [24]. 
Indeed, an unjust system, regardless of its possibly active redistribution, cannot offset the systemic dispossession it is creating [33]. In this sense, economic democracy represents a distinct approach to challenging inequality, as it tries to have a comprehensive analysis of the economy as a whole to rebuild structural equality, challenging the unjust system itself [29]. This view is echoed by Schweickart [34], who maintains that economic democracy is a system model able to preserve a role for markets in goods and services, while extending democracy into the workplace and the linked spheres of finance and investment. Such a system model requires to rethink and democratize ownership and challenge the existing growth paradigm to construct a cooperative, caring, and community-nurturing economy that is ecologically sustainable, economically equitable, and socially responsible [23].

Briefly speaking, first, the literature on approaching socioeconomic inequality commonly, no matter economic democracy, ownership reform, empowerment, or institutional engagement, concerns essentially a social innovation process. Second, prevailing conception of economic democracy relates it to self-governance, empowerment, and ownership [18], [19], [6], [20], [21], [22]. However, the socioeconomic environment where social innovation and economic democratization actually take place draws relatively little attention. Besides, although advocates of economic democracy have legitimately proposed 'a systemic approach to a systemic problem', a macro-concept of 'ecosystem' is missing in their statement. This can be problematic as it is in a dynamic 'ecosystem' that socioeconomic inequality occurs, which makes it a multi-dimensional issue.

Truly, economy cannot be perceived as isolated; rather, it must be considered as a 'system' showing the inter-dependence between its own subsystems and the broader external ecosystem [25]. Failing to address socioeconomic problems with a systemic approach explains why well-intentioned social investments have seldom created economically viable communitybased businesses able to harness the community's own spending power and external resource flows [24]. As an alternative to the isolated, static view of economics, Nobbs [25] advocates a 'system approach' to economics: ecological economics. Such an approach, in response to the prevailing mania of economic efficiency and digital growth, emphasizes not only market processes, but 'ecological processes' - both human and natural. This ecology-based economics recognizes that, on the one hand, economic processes are rooted in human society governed by the laws of natural science, and on the other hand human society itself is subject to the natural world and as such is part of a complex and adaptive ecosystem. A 'system approach' to economics is considered as highly beneficial to the 'knowledge economy'. Entrepreneurship is thought to depend heavily on a knowledge ecosystem, as a region's capabilities to activate, develop, sustain and manage knowledge dynamics and processes determine its entrepreneurial vitality [26]. Knowledge and skills from a diversity of people connected in a network can fuel the process of innovation [27]. This is especially true in terms of social innovation, wherein networks of knowledge and actions are critical to what Esteva [28] calls 'post-economic events', which make the public aware of the limits of development and spur civil coalitions to gain political controls on the economic sphere while re-embedding economic activities in the social fabric.

A systemic approach also starts emerging in defining economic democracy. Malleson [29] conceives of economic democracy as a 'system' that offers a broad framework for thinking about how people are affected differently by economic power, and how it can remain socially and economically accountable. As a system, economic democracy has an institutional implication that, multi-sectoral collaboration is most likely to trigger large-scale social change rather than isolated intervention by individual organizations [30]. In this sense, coupling 
public, private and civil institutions and local communities is critical to driving social innovation and economic democratization. Within the system of economic democracy, workplaces, finance, investment, and market are the four cornerstone constituents [29]. If economic democracy is to effectively remedy socioeconomic inequalities, it is indispensable to adopt a 'system thinking' that highlights the interplay between, inter alia, the four constituents.

Connecting with knowledge economy, economic democratization can be promoted through a social innovation process. Knowledge economy shows three major characteristics: global, highlighting intangible assets, and intensely interlinked [42, 43]. Knowledge, as a key element in innovation process, is considered to be an economic driver [44, 45, 39, 46, 47]. Technological innovation, like ICT, is vital to the development of knowledge economy and economic growth [48], [49], [1], [36]. However, knowledge economy is not evenly distributed across space [50]. Low-skilled workers are vulnerable to new economy development [32], [50]. This problem can be solved through economic democratization that empowers employees to gain ownership and accountability [51], which often brings about increased value generation and more balanced complex relationships between different stakeholders [52]. Employee ownership and accountability offer businesses competitive advantages and better economic performance by reducing resource dependence while increasing cooperation among internal stakeholders [53], [54] and fostering business specific human capital, which is a valuable basis for competitive advantages [52], [55]. In the economic democratization process, social innovation guided by a ,system thinking' plays a crucial role. On the one hand, social innovation is vital to the development of competitive advantages [38, 39], which are conceptualized as a contextualized interactive learning process $[38,40]$. The capacity of localities to support processes of learning and innovation is believed to be a key contributing factor to competitive advantages [40]. On the other hand, a systemic approach is critical to creating an optimal social innovation environment, in that it can not only create competitive advantages, but opportunities for co-creation of shared social values, which in turn reinforce competitive advantages [41].

\section{OBJECTIVES AND METHODOLOGY}

This research investigates how a place-based and multi-stakeholder innovation ecosystem promotes economic democratization and helps address socioeconomic inequality by understanding evidence from the Boston Ujima Project (BUP) case study. Therefore, it is conducted with a mixed-methods approach that combines the objective-oriented literature review, quantitative data for 'place' analyses, and semi-structured interviews for the Ujima innovation ecosystem. The aim, based on case study discussions, is to conceptualize an ecosystem-based innovation approach to address socioeconomic inequalities.

First, the literature review looks into existing studies on economic democracy and, system approach'. On the one hand, it discusses on economic democracy focusing on self-governance, empowerment, and ownership and its relevance to the mitigation of socioeconomic inequalities. On the other hand, the literature review summarizes discussions on a systemic approach to economy and economic democracy, which highlights ,system thinking'. Second, qualitatively, the research carries out a case study of the BUP to illustrate how its innovation ecosystem helps to mitigate socioeconomic inequalities in Boston. The case study starts with the concept of ,place' highlighted by the BUP and examines the spatial distribution of socioeconomic inequalities in Eastern Massachusetts where the BUP is operating. Then, it discusses the BUP's ideology and dynamics, focusing on the Ujima innovation ecosystem and its role in promoting economic democratization in a systemic way. Finally, it explores the 
economic empowerment mechanism promoted by the BUP's economic democratization process. The case study is conducted with literature review of both academic resources and the official website of the BUP, quantitative data, and semi-structured interviews. In terms of quantitative data, the research retrieved data from the U.S. Census Bureau on demography and economy of both poor and better-off cities, including racial structure, median household income, poverty rate, educational attainment, etc. so as to illustrate the spatial distribution of socioeconomic inequalities in Eastern Massachusetts. In order to deepen its understanding of the methodology of the BUP to build up the innovation ecosystem, it administered semistructured interviews with the BUP's key institutional components, including the directors or focus points of City Life/Vida Urbana, Boston Impact Initiative, and Access Strategies Fund.

\section{THE CASE STUDY OF BOSTON UJIMA PROJECT}

Nowadays, escalating socioeconomic inequalities urge us to advance equitable cooperation [20]. It also stipulates us to acquire capacities for structural adjustment to new ways of organizing productive activities, so as to gain competitive advantages by taking full advantage of technological innovation [61]. The Boston Ujima Project (BUP), led by the Center for Economic Democracy (CED), came into being in 2015 just to meet this need by creating innovative ways to invest, work, buy, own, and advocate for fighting against socioeconomic inequalities in Boston on the one hand and shape economic democracy at the community level on the other. Ujima, as one of the seven principles of Kwanzaa (or Nguzo Saba), means, collective work and responsibility' in Swahili.

Officially launched at its Inaugural General Assembly in September 2017 after a one-year participatory research, followed by a one-year participatory planning, the BUP integrates community-controlled business and diversified financing strategies with community organizing strategies. The participatory research was carried out by an extensive cross-sector study group composed by leaders investing in Boston's low-income communities and communities of color (LIC\&COC). The participatory planning engaged community residents, grassroots organizations, small businesses, capital providers, and advisors and took a variety of forms, including interactive workshops, interviews, focus groups, and working groups.

With a place-based, systemic, and multi-stakeholder approach, it is aimed to help LIC\&COC gain control over capital, grow cooperatives and land trusts, and protect locally owned businesses from capitalist corporate economy. To achieve these objectives, it leverages the power of investing and organizes neighbors, workers, business owners and investors to create a community-controlled economy, i.e. a 'solidarity economy', bring about positive socioeconomic change, and build up self-governing communities characterized by cooperative work and responsible production and consumption.

\subsection{Place and communities}

According to Allard [62], there are clear connections between place, racial segregation, and concentrated poverty in urban and rural communities. A key focal point today in joining economic inequality with racial inequality recognizes how place structures inequality [63]. Sharkey [64] argues that the perpetuating racial inequality in the US should be perceived not only as a policy failure, but as a failure to conceptualize the role that places play in the production and maintenance of inequality across multiple dimensions. Widestrom [37] also highlights the importance of civil environment of a given 'place', which through dynamic interaction of social networks, economic and business entities, and institutions, can largely 
impact civil engagement and participation. In fact, the concept of 'place' in relation to growth and development [65-68] is gaining increasing academic and political attention, and it is believed that places are capable of growing in an organic way by capitalizing on their embedded resources, especially human capital and innovative capacities [68]. Moreover, 'place' has a direct impact on human development, as it can shape the potentials both for territorial development and individual development within it through positive externalities [65]. Social innovation must be place-based as well, so as to connect its economic impact with the spatial dimension of economic activities [1]. In addition, a place-based approach helps to avoid competition for footloose capital which undermines democracy as resulting policies are meant to attract off-limits, fair-weather investments while showing no social concern [4].

The BUP highlights the significance of 'place' and 'people' and their interplay in order to contextualize its interventions and meanwhile harnesses embedded community assets such as the political power, investment power, and consumption power. It seeks to enhance a sense of place and create and retain wealth within local communities. The BUP is operating mainly in Eastern Massachusetts, which covers major cities such as Lowell, Lawrence, New Bedford, Fall River, Brockton, Chelsea, Everett, Worcester, and Malden. Table 1 shows the socioeconomic status quo of these cities. To illustrate the spatial inequality, the table also includes better-off cities in Greater Boston, including Newton, Cambridge, Somerville, and Medford.

As Table 1 demonstrates, Lowell, Lawrence, New Bedford, Fall River, Brockton, Chelsea, Everett, Worcester, and Malden share many similarities with regard to racial structure, median

Table 1: Demography, income, education and poverty in Eastern Massachusetts and Greater Boston.

\begin{tabular}{lllll}
\hline City & Population $^{1}$ & White $^{2}$ & Non-White (\%) & Median Age $^{3}$ \\
\hline Lawrence & 80,209 & 37,328 & 53.46 & 31 \\
New Bedford & 95,032 & 66,505 & 30.02 & 37.3 \\
Worcester & 184,508 & 127,621 & 30.83 & 34 \\
Fall River & 88,930 & 73,370 & 17.50 & 39.4 \\
Lowell & 110,558 & 64,569 & 41.60 & 33 \\
Boston & 673,184 & 348,906 & 48.17 & 31.7 \\
Chelsea & 39,699 & 18,617 & 53.10 & 32.8 \\
Brockton & 95,630 & 42,238 & 55.83 & 35.9 \\
Malden & 60,840 & 33,807 & 44.43 & 36 \\
US & $323,127,513$ & $233,657,078$ & 27.69 & 37.7 \\
Everett & 46,340 & 27,060 & 41.61 & 34.9 \\
Cambridge & 110,651 & 72,974 & 34.05 & 30.5 \\
Somerville & 81,322 & 60,145 & 26.04 & 31.6 \\
MA & $6,811,779$ & $5,343,665$ & 21.55 & 39.4 \\
Medford & 57,213 & 44,754 & 21.78 & 35.9 \\
Newton & 89,045 & 68,725 & 22.82 & 40.8 \\
\hline
\end{tabular}


Table 1: (Continued)

\begin{tabular}{llll}
\hline City & Median household income & & $\begin{array}{l}\text { High school or higher } \\
\text { educational attainment }\end{array}$ \\
\hline Lawrence & 36,754 & 26.40 & 67.50 \\
New Bedford & 38,178 & 23.50 & 72.60 \\
Worcester & 45,599 & 22.10 & 84.40 \\
Fall River & 36,798 & 22.00 & 72.10 \\
Lowell & 46,972 & 21.50 & 79.70 \\
Boston & 58,516 & 21.10 & 85.70 \\
Chelsea & 49,614 & 19.30 & 67.20 \\
Brockton & 49,956 & 18.20 & 81.40 \\
Malden & 60,085 & 15.30 & 86.00 \\
US & 55,322 & 15.10 & 87.00 \\
Everett & 52,457 & 14.60 & 80.80 \\
Cambridge & 83,122 & 14.00 & 94.10 \\
Somerville & 78,673 & 13.30 & 89.80 \\
MA & 70,954 & 11.40 & 90.10 \\
Medford & 79,607 & 10.50 & 92.00 \\
Newton & 127,402 & 4.40 & 97,10 \\
\hline
\end{tabular}

${ }^{1}$ Total Population: 2016 Population Estimates ${ }^{2-6}$ 2012-2016 American Community Survey 5-Year Estimates

Source: United States Census Bureau American FactFinder.

household income, poverty rate, educational attainment, etc. In terms of racial structure, these cities generally have considerable number of non-white residents, especially in Lawrence, Brockton and Chelsea where more than half of the population are non-whites. Except Fall River, all of them have far more non-white population than in Massachusetts and the US. Regarding age, most of these cities have younger population than in Massachusetts and the US. Except Malden, these cities have much lower median household income than in Boston, Massachusetts and the US, which partially explains their much higher poverty rate than in Massachusetts and the US. Their level of education attainment gives a worrying picture as well, which is lower than that of Boston, Massachusetts and the US. In contrast, in better-off cities like Newton, Cambridge, Somerville, and Medford, there are smaller nonwhite population than in the US except for Cambridge. They have much higher median household income than in Boston, Massachusetts and the US, which partially explains their lower poverty rate. As for educational attainment, generally they have more people with high school and higher certificate than in Boston, Massachusetts and the US. The contrast between the two groups of cities not only shows the spatial distribution of socioeconomic inequalities in Greater Boston but affirms the rationale of adopting a place-based, 'system thinking' approach to effectively address them. In the following sections, the research looks into how, with such an approach, the BUP builds up its innovation ecosystem and the economic democratization mechanism underlying it. 


\subsection{Ujima innovation ecosystem}

The pronounced mission of the BUP is to build up a democratic community development organization, where various stakeholders, including residents, workers, small businesses, grassroots organizations, can cooperate and collaborate within the socioeconomic sphere. To realize this mission, the BUP has constructed and keeps growing a complex innovation ecosystem and spurs local communities to organize their economic, sociocultural and political activities within it. In essence, the Ujima innovation ecosystem is a 'community controlled open-innovation' system [69], in that it utilizes purposive inflows and outflows of knowledge to accelerate internal innovation while combining both internal and external knowledge and pathways to market and system building [70]. This ecosystem, owing its formation largely to 'system thinking' and relationships, plays an important role in generating community power which is built in organizations, coalitions, networks, and movements [71]. As 'system thinking' requires the coupling between natural ecological systems and human social systems [25], the Ujima innovation ecosystem couples the 'place' (the natural ecological system) and socioeconomic dynamics (human social system). Regarding its human social dimension, the Ujima innovation ecosystem is both an innovating community organizing system and an innovating business and financing system. Based on 'place' and centered on people, the Ujima innovation ecosystem's development is driven by three major dynamics, i.e. multistakeholder relationships and networks (social), diversified investment and democratized economic decision-making (economic), and democratic self-governance (political), as Table 2 and Fig. 1 show.

The Ujima innovation ecosystem serves as a systemic way to promote economic democratization as it synergizes the social, economic and political dynamics embedded in the 'place'. In so doing, the BUP distinguishes itself from the conventional non-profit sector that tends to operate with an ,isolated impact' approach [30]. First, socially and institutionally, its collaborative multi-stakeholder dynamics is typically a problem-solving strategy grounded in the integration of all social relations into, a democratic framework' [18] critical to promoting cooperation and participatory democracy [27], [37]. Besides its positive impact on democratization, the multi-stakeholder dynamics, on the one hand, has laid the cornerstone for the Ujima innovation ecosystem by developing its social capital bonds of reciprocity [27] and fortifying its structural capital, which is the embodiment, empowerment, and supportive infrastructure of human capital [72]. As a result, a new culture of cooperation and collaboration within communities starts to emerge. Through cooperation and collaboration, communities can not only overcome the negative externalities of corrosive competition and diseconomies of scale [36], but also promote the social process of knowledge generation which, vital to social innovation, is by nature a function of collaboration between community members [57]. On the other hand, this multi-stakeholder dynamics grounded in relationshipbased collaboration is highly supportive to small businesses, which often work most efficiently in geographically clustered networks that promote the exchange of information, knowledge, skill and finance [36].

Second, economically, the Ujima innovation ecosystem actively responds to the classic problem that poor neighbourhoods tend to have troubled access to debt and equity capital, which represents a formidable barrier to entrepreneurship and business growth [24]. On the one hand, diversified investment tools and types help satisfy different financing needs of different businesses and real estate projects. The funding to microbusinesses, start-ups and small businesses plays an extremely important role in shaping local communities' economic landscape. 
Table 2: Three major dynamics driving the Ujima innovation ecosystem's development.

\begin{tabular}{|c|c|c|}
\hline \multicolumn{2}{|c|}{ Major dynamics } & \multirow{2}{*}{$\begin{array}{l}\text { Main actions } \\
\text { Building relationships and networks between } \\
\text { a variety of community members, institutions } \\
\text { (grassroots and civic organizations, unions and } \\
\text { foundations involved in sociocultural, economic and } \\
\text { political issues) and the private sector (businesses, } \\
\text { funders, investors, developers). }\end{array}$} \\
\hline $\begin{array}{l}\text { Social } \\
\text { Dynamics }\end{array}$ & $\begin{array}{l}\text { Multi-stakeholder } \\
\text { relationships and } \\
\text { networks }\end{array}$ & \\
\hline \multirow[t]{2}{*}{$\begin{array}{l}\text { Economic } \\
\text { Dynamics }\end{array}$} & $\begin{array}{l}\text { Diversified } \\
\text { investment }\end{array}$ & $\begin{array}{l}\text { Tools: 'whole portfolio', e.g. loans, credit } \\
\text { enhancements, equity investments, royalty financing, } \\
\text { DPOs (direct public offerings), crowdfunding, co- } \\
\text { investing, grants; } \\
\text { Types: microfinance, start-ups, small businesses, } \\
\text { growth businesses, real estate investments, and } \\
\text { infrastructural investments (ordered with an } \\
\text { increasing funding range). }\end{array}$ \\
\hline & $\begin{array}{l}\text { Democratized } \\
\text { economic decision- } \\
\text { making }\end{array}$ & $\begin{array}{l}\text { Collectively determining good businesses to invest; } \\
\text { One member, one equally weighted vote regardless of } \\
\text { their share in the Community Capital Fund. }\end{array}$ \\
\hline \multirow[t]{3}{*}{$\begin{array}{l}\text { Political } \\
\text { Dynamics }\end{array}$} & $\begin{array}{l}\text { Democratic self- } \\
\text { governance }\end{array}$ & $\begin{array}{l}\text { Highest governing body: General Assembly; } \\
\text { Vote on or change Ujima's Governing Charter; } \\
\text { Vote on representatives to the Ujima Board of } \\
\text { Directors; } \\
\text { Set community standards; } \\
\text { Vote on the goals for collective investments; } \\
\text { Endorse campaigns. }\end{array}$ \\
\hline & & $\begin{array}{l}\text { Local governing bodies: Neighborhood Assemblies; } \\
\text { create and vote on a Neighborhood Plan; } \\
\text { approve investments made to neighborhood } \\
\text { businesses; } \\
\text { request resources and funding from the General } \\
\text { Assembly. }\end{array}$ \\
\hline & & $\begin{array}{l}\text { Ad hoc governing bodies: Caucuses; } \\
\text { More inclusive decision-making accountable to those } \\
\text { previously excluded social groups. }\end{array}$ \\
\hline
\end{tabular}

Source: The Authors

This is mainly because there exists a capital gap in the mainstream finance: few conventional lenders would make as small loans or investments as $\$ 2,500 \sim \$ 10,000$ to microbusinesses. While existing community-based microfinance institutions like Accion and Grameen finance may make such loans, they charge an interest rate of $8.99 \%-15 \%$. In contrast, the BUP offers small loans to microbusinesses at a lower even zero interest rate than existing microfinance institutions. Besides, grounded in its extended relationships and networks, the BUP provides them with more funding options by partnering with other small business lending institutions 


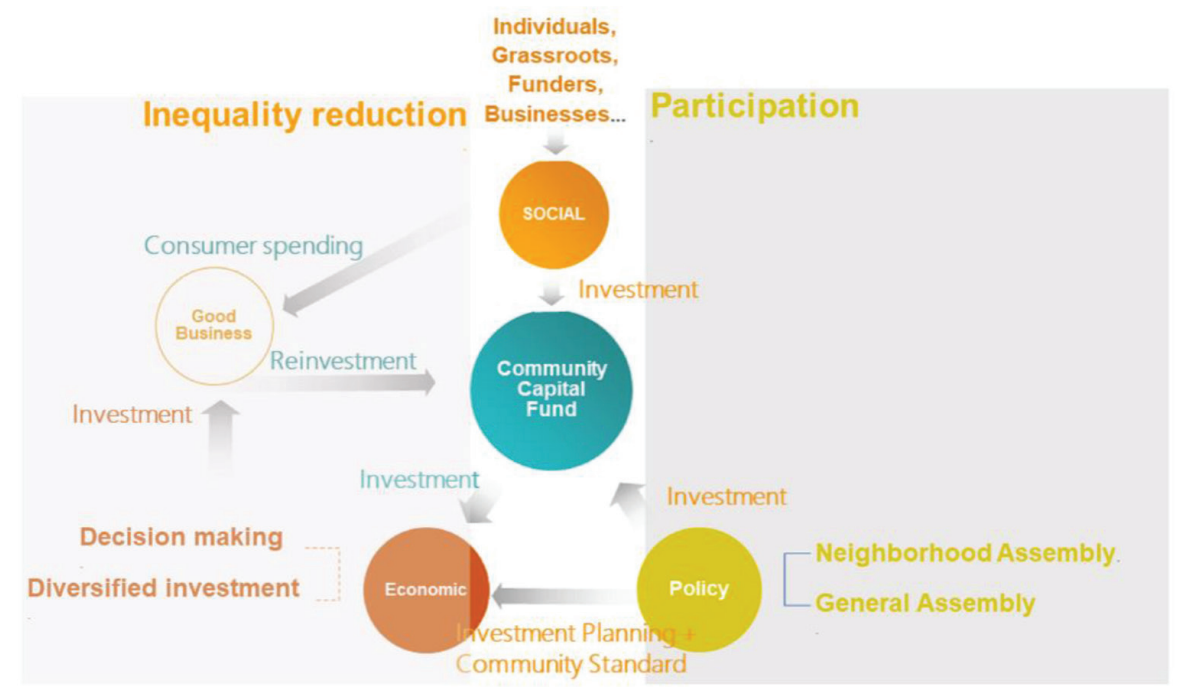

Figure 1: Innovation ecosystem of the Boston Ujima project.

Source: The Authors

to increase their access to capital. Besides capital investment, community-rooted businesses are also able to apply for free office space and business coaching. This marks a meaningful shift of investment finance away from models of competition and profit towards models of community and support. On the other hand, with a democratized economic decision-making, the BUP is able to allocate democratically its pooled fund based on community needs and common interests instead of individual interests of the investors with more share in the Community Capital Fund (CCF). More importantly, it fosters a solidarity-based cooperative culture within communities and thereby curtails possible conflict of interests. At its 'Boston Solidarity Summit' in 2016 where it tested its CCF for the first time, the BUP allocated through a democratic voting process, at zero loan interest rate, a fund of $\$ 20,000$ pooled from over 175 small lenders and investors to five Black and immigrant owned businesses. The loans were mainly used to purchase business equipment such as industrial printer, Point of Sale System, etc.

Third, politically, the Ujima innovation ecosystem is highly supportive to democratic selfgovernance, which has largely promoted the economic democratization process. As Table 2 shows, the BUP's three-layer democratic self-governance not only provides operational principles to guide the allocation of the $\mathrm{CCF}$, but creates a democratic political framework to spur civil participation. This framework on the one hand makes democratic self-governance a right to all Ujima members. Workers of small businesses, due to their fragile employment situation, tend to be weakly mobilized politically [32]. With this right, they are in a position to take an important step toward attaining equality, justice, efficiency, and liberty both politically and economically [73]. On the other hand, civil participation functions as the critical means by which significant social reform can be induced through the redistribution of power that enables powerless citizens to be engaged in the political and economic processes [48]. It also helps challenge the socioeconomic status quo by organizing collective actions that largely depend on voluntary participation, shared commitments, and persisting momentum [74]. 


\subsection{Economic empowerment}

Advocates of economic democracy have accused the current financial system in three facets. First, it fails to provide a reliable, trustworthy public service of credit provision; second, it fails to provide citizens with democratic oversight over how fund is allocated, hence little accountable; third, it gives private financiers too much power over public institutions [29] (p. 91). Consequently, big corporations often drive out small businesses, leading to further concentration of capital. This is worsened by neoliberal regulations, which privilege profitmaximization corporations while being particularly burdensome for small businesses [7]. Indeed, capital is central to an equitable development in inner urban areas due to two disadvantages they commonly have: poor access to debt funding and absence of equity capital [24]. Frequently, capital investment, when under the control of the private sector, implies a democratic issue wherein it excludes the civil society from engaging in active democratic oversight over the pathways of future investment [29]. In order to help local communities in gaining a control over capital, the BUP adopts a fivefold strategy to promote economic empowerment, as is shown in Table 3.

It can be said that the five-fold strategy offers a set of localized methods to promote economic empowerment. Its strengths can be summarized as follows. First, the Good Business Alliance (GBA) can improve the overall reputation of Ujima businesses by strengthen their social responsibility. This contributes to their competitive success [75] and enables them to

Table 3: The BUP's fivefold strategy to promote economic empowerment.

\begin{tabular}{|c|c|}
\hline Sub-strategies & Main actions \\
\hline Good Business & Determined by community standards; \\
\hline Alliance (GBA) & $\begin{array}{l}\text { Ethical business practices like living wages, local purchasing, } \\
\text { environmental impact, affordability, etc.; } \\
\text { Free community promotions to improve visibility; } \\
\text { Access to capital, technical assistance, cooperative purchasing and } \\
\text { joint ventures to strengthen operations and market share. }\end{array}$ \\
\hline $\begin{array}{l}\text { Community Capital } \\
\text { Fund (CCF) }\end{array}$ & $\begin{array}{l}\text { Crowdfunded; dedicated to community-controlled investment; } \\
\text { Pooling idle capital, e.g. individual savings and private lending } \\
\text { resources from membership networks; } \\
\text { Capital from universities, union pension funds and foundation } \\
\text { endowments; } \\
\text { Democratically governed and allocated. }\end{array}$ \\
\hline $\begin{array}{l}\text { Worker Services } \\
\text { Network (WSN) }\end{array}$ & $\begin{array}{l}\text { Human resource programs, e.g. group health insurance, internal } \\
\text { staffing agency, workplace mediation services; } \\
\text { Mutual-aid programs, e.g. skill share, time trades. }\end{array}$ \\
\hline $\begin{array}{l}\text { Alternative Local } \\
\text { Currencies (ALC) }\end{array}$ & $\begin{array}{l}\text { Internal electronic currency offering discounts at Good Businesses; } \\
\text { interest free credit for B2B purchasing; } \\
\text { Time Bank allowing for skills/labour trade among neighbors. }\end{array}$ \\
\hline $\begin{array}{l}\text { Anchor Institution } \\
\text { Advocacy (AIA) }\end{array}$ & $\begin{array}{l}\text { Organizing the political power embedded in communities; } \\
\text { Advocating the concept of 'buy local' to public institutions. }\end{array}$ \\
\hline
\end{tabular}

Source: The Authors 
capture the value of social goods and use it as a strategic resource: the value of reputation can be harnessed through premium pricing or consumer loyalty, or a potential decrease of personnel and capital costs [76]. Second, the Community Capital Fund (CCF) is a vital platform to gain control over community capital and exercise collective economic democracy. Third, the Worker Services Network (WSN) helps grow employee satisfaction and security, given that most small and medium businesses often have difficulty in delivering strong supports and benefits to their employees due to limited resources and unions. It is also beneficial especially to lower-skilled workers who often show a strong interest in job training and human capital development [32]. Fourth, the Alternative Local Currencies (ALC) encourages purchasing and trade and captures local spending, and thereby helps grow local wealth by ensuring the circulation of resources within the Ujima innovation ecosystem. This is also an indirect way to strengthen small businesses' competitiveness, thus protecting community-owned small businesses from overwhelming corporate companies. According to the ,2016-2017 Ujima Vendor Report', local spending, especially by people of colour (POC), has become predominant in communities under intervention (Fig. 2). Fifth, the Anchor Institution Advocacy (AIA) helps the BUP to scale its impact on economic democracy and grow its ecosystem, by gaining broader external political and financial support. Last but not the least, both the GBA and ALC are important tools to forge responsible and conscious consumption within local communities.

\section{DISCUSSIONS AND CONCLUSIONS}

The Boston Ujima Project (BUP) has provided a powerful alternative to capitalist economic system by going beyond efficiency-oriented and equality-oriented capitalism [23], [29], [18]. It has actually walked a 'middle way' out through an 'institutionalized social knowledge process' underpinned by 'diversity' rather than 'unity', and heterogeneous competing and complementary approaches instead of a paradigm of convergence [25]. The BUP has responded to the 'local participation, central power' limitation of today's democracy [77] and reconciled it by creatively aligning both local participation and community political economic power building. By incorporating community cooperation and organizing, participatory decision-making and budgeting, impact investing with integrated capital tools, and community-controlled businesses into one comprehensive ecosystem, the BUP has promoted the economic democratization and self-governance of local communities by empowering them both politically and economically. Therefore, it can be concluded that, as Fig. 3 depicts, the BUP has established a novel concept of political system that strives for economic democracy

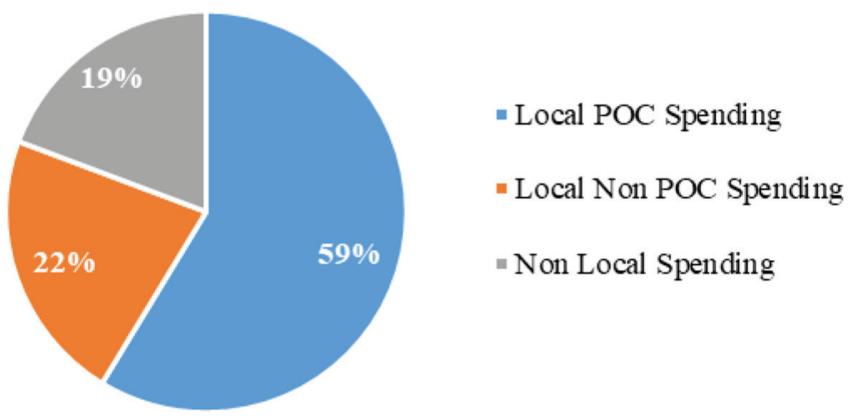

Figure 2: Proportion of local and non-local spending. Source: Boston Ujima Project 2017 


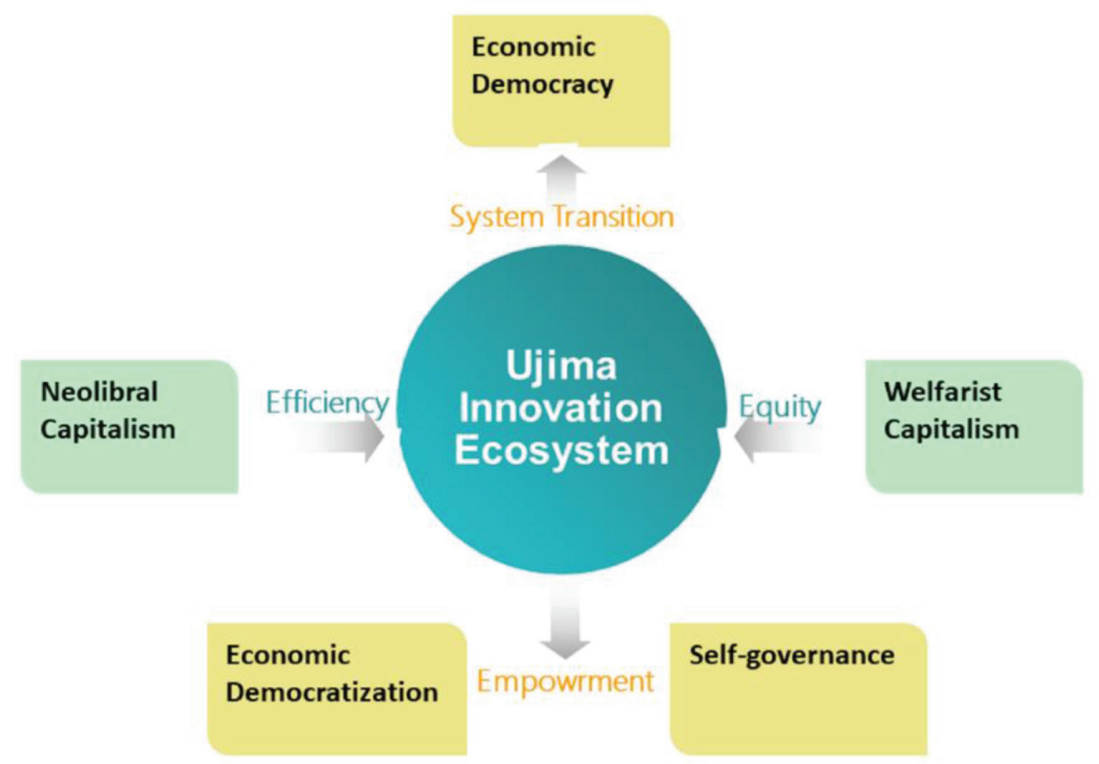

Figure 3: The Ujima Political System based on economic democracy. Source: The Authors

grounded in an innovation ecosystem, which, rooted in 'place' and 'system thinking', is built up by multi-stakeholder relationships and networks (social), diversified investment and democratized economic decision-making (economic), and democratic self-governance (political). Concurrently, it is tenable to argue that this innovation ecosystem enables the BUP to promote economic democratization and thereby provide a set of effective tools to address socioeconomic inequalities of the targeted low-income communities. Besides, by gaining control over capital and fostering local asset-based and network-based social innovation, it has not only enabled local communities to adjust themselves to the knowledge economy, but mitigate the polarization externality triggered by it. In so doing, the BUP contributes to an equitable distribution of the competitive advantages that the knowledge economy generates. The BUP's adoption of a multi-stakeholder approach to economic decision-making has marked a process of social innovation, which has transformed local communities' socioeconomic landscapes by directly empowering the citizens with accountability rather than counting on centralized decision coming from the ruling classes [27, 56, 59]. In addition, multi-stakeholder economic decision-making paves the way for participatory budgeting, which, as an institutional innovation, is an important democratic experiment and experience [78]. This is because that participatory budgeting can transform public understanding of economic democracy from its currently passive to a more active concept, a premise for civil engagement in socioeconomic processes [78]. Participation is vital to achieving the BUP's objective of economic democracy. Indeed, it has stuck to a participatory approach throughout its implementation, in terms of organizing, planning, governance, and decision-making. Nevertheless, a tension exists between the need to ground decision-making in core constituent groups of low-income communities and the necessity to allow external ones to participate meaningfully [71]. 
The BUP is highly relevant to social innovation as it has set up good empirical examples in terms of governance mechanism, community standards setting, and organization growing pattern. First, with regard to the BUP's governance mechanism, its 3-layer self-governance, namely, General Assembly, Neighbourhood Assemblies, and Caucuses, create a joint force to model economic democracy within Ujima communities, offering an important method for challenging capitalist political democracy. Such a self-governance pattern has expanded the democratic accountability to a significant extent through representation, collective deliberation, and particularly direct participation in economic decision-making, which is crucial for addressing the structural inequality [29]. Second, setting community standards for businesses is very beneficial to the formation of new economic and social culture within communities. On the one hand, community standards help determine good businesses that should receive investment funds and be protected from corporate capitalism. On the other hand, they also lead community members to reshape their consumption behaviors and become conscious and responsible consumers, therefore helping grow community-controlled economy. Besides, these standards are tools for launching campaigns to secure procurement from anchor institutions. Third, the BUP, as a new organization, has demonstrated an incrementalist approach [79] to grow itself rather than directly seeking partnerships with larger institutions. This incremental growth is not only a prerequisite to grow the Ujima innovation ecosystem in an 'ecologically organic' way but enables the BUP to build up a solid 'field' by accumulating community power and support from the public, private and civil sectors. This explains why, with a rather limited funding for operations, the BUP was able to successively set up and test its Community Capital Fund in 2016.

Due to BUP's short running time so far, the study has showed the viability of modeling economic democracy within an innovation ecosystem based on the BUP's implementation in progress, starting from the literature limitation. The evaluation of outcomes will be a further development of the research. The BUP Framework analysis, nevertheless, can offer prospects on alternative ways to model urban transformation and local development. Forthcoming research will be able to compare the BUP to other grassroots-led projects dedicated to promoting 'solidarity economy', to figure out a more complete landscape of economic democratization driven by social innovation.

\section{ACKNOWLEDGEMENTS}

This research work is part of the MAPS-LED research project (Multidisciplinary Approach to Plan Smart Specialisation Strategies for Local Economic Development), which has received funding from the European Union's Horizon 2020 research and innovation programme under the Marie Skłodowska-Curie grant agreement No. 645651. The Grant No. 645651 covers also the costs to publish in open access.

\section{REFERENCES}

[1] Hübner, K., Space of innovation: Introductory remarks on the comparative analysis of the new economy. In The New Economy in Transatlantic Perspective, ed. K. Hübner, Routledge: London and New York, pp. 3-19, 2005.

[2] Cozzens, S., Innovation and Inequality: A View from the South. Brookings Institution, 2016. Available at https://www.brookings.edu/ (accessed 19 December, 2017).

[3] Chakravorty, S., Fragments of Inequality: Social, Spatial and Evolutionary Analyses of Income Distribution, Routledge: New York and London, 2014.

[4] Madeley, J., A People's World: Alternatives to Economic Globalization, Zed Books: New York and London, 2003. 
[5] Speth, J.G., American passage: Towards a new economy and a new politics. Ecological Economics, 84, pp. 181-186, 2012. https://doi.org/10.1016/j.ecolecon.2011.01.018

[6] Panayotakis, C., Remaking Scarcity: From Capitalist Inefficiency to Economic Democracy, Pluto Press: Chicago, 2011.

[7] Harvey, D., The Enigma of Capital and the Crises of Capitalism, Oxford University Press: New York, 2010.

[8] Henwood, D., After the New Economy, The New Press: New York, 2003.

[9] Bevilacqua, C., Pizzimenti, P. \& Maione, C., S3: Cluster Policy \& Spatial Planning: Knowledge Dynamics, Spatial Dimension and Entrepreneurial Discovery Process. Report, MAPS-LED Project, Horizon2020 MSCA RISE, 2017.

[10] Bartels, L.M., Unequal Democracy: The Political Economy of the New Gilded Age, 2nd edn., Princeton University Press: Princeton, 2016.

[11] Savoia, A., Easaw, J. \& Mckay, A., Inequality, democracy, and institutions: A critical review of recent research. World Development, 38(2), pp. 142-154, 2010. https://doi. org/10.1016/j.worlddev.2009.10.009

[12] Aghion, P., Caroli, E. \& García-Peñalosa, C., The perspective of the new growth theories. Journal of Economic Literature, 37, pp. 1615-1660, 1999.

[13] Castelló-Climent, A., Inequality and growth in advanced economies: An empirical investigation. The Journal of Economic Inequality, 8(3), pp. 293-321, 2010. https://doi. org/10.1007/s10888-010-9133-4

[14] Cingano, F., Trends in income inequality and its impact on economic growth. OECD Social, Employment and Migration Working Papers, Paris: OECD Publishing, 2014.

[15] Delbianco, F., Dabús, C. \& Caraballo, M.A., Income inequality and economic growth: new evidence from Latin America. Cuadernos de Economía, 33(63), pp. 381-398, 2014. https://doi.org/10.15446/cuad.econ.v33n63.45338

[16] Fawaz, F., Rahnama, M. \& Valcarcel, V.J., A refinement of the relationship between economic growth and income inequality. Applied Economics, 46(27), pp. 3351-3361, 2014. https://doi.org/10.1080/00036846.2014.929624

[17] Persson, T. \& Tabellini, G., Is inequality harmful for growth? The American Economic Review, 84(3), pp. 600-621, 1994.

[18] Schweickart, D., Economic democracy: A worthy socialism that would really work. Science and Society, 56(1), pp. 9-38, 1992.

[19] Wolff, N.E., The asset price meltdown and the wealth of the middle class. National Bureau of Economic Research Working Paper Series, 2012. doi:10.3386/w18559

[20] Hahnel, R., Economic Justice and Democracy: From Competition to Cooperation, Routledge: New York, 2005.

[21] Archer, R., Economic Democracy: The Politics of Feasible Socialism, Clarendon Press: Oxford, 1995.

[22] Johanisova, N. \& Wolf, S., Economic democracy: A path for the future? Futures, 44(6), pp. 562-570, 2012. https://doi.org/10.1016/j.futures.2012.03.017

[23] Alperovitz, G., Speth, J.G. \& Guinan, J., The Next System Project: New Political-Economic Possibilities for the 21st Century, 2015. Retrieved from https://thenextsystem. org/sites/default/files/2017-08/NSPReport1_Digital.pdf (16/12)

[24] Porter, M.E., The competitive advantage of the inner city. Harvard Business Review, pp. 55-71, 1995.

[25] Nobbs, C.L., Economics, Sustainability, and Democracy: Economics in the Era of Climate Change, Routledge: Abingdon, Oxon, New York, 2013. 
[26] Cabrita, M.R., Cabrita, C., Matos, F. \& del Pilar Muñoz Dueñas, M., Entrepreneurship capital and regional development: A perspective based on intellectual capital. In Entrepreneurship, Human Capital, and Regional Development: Labor Networks, Knowledge Flows, and Industry Growth, eds. R. Baptista \& J. Leitão, Springer Switzerland: Cham, pp. 15-28, 2015.

[27] Harrisson, D., Bourque, R. \& Széll, G., Social innovation, economic development, employment and democracy. In Social Innovation, the Social Economy and World Economic Development, eds. D. Harrisson, R. Bourque \& G. Széll, Peter Lang: Frankfurt am Main, New York, pp. 7-16, 2009.

[28] Esteva, G., Development. In The Development Dictionary, A Guide to Knowledge as Power, ed. W. Sachs, Zed Books Ltd.: London and New York, pp. 6-25, 1992.

[29] Malleson, T., Economic democracy: The left's big idea for the twenty-first century? New Political Science, 35(1), pp. 84-108, 2013. https://doi.org/10.1080/07393148.2012.754670

[30] Kania, J. \& Kramer, M., Collective impact. Stanford Social Innovation Review, Leland Stanford Jr. University, 2011.

[31] Kim, K.S., Income distribution and poverty: An interregional comparison. World Development, 25(11), pp. 1909-1924, 1997. https://doi.org/10.1016/s0305-750x(97)00080-6

[32] Beramendi, P., Häusermann, S., Kitschelt, H. \& Kriesi, H. (eds)., The Politics of Advanced Capitalism, Cambridge University Press: New York, 2015.

[33] Venn, C., Neoliberal political economy, biopolitics and colonialism: A transcolonial genealogy of inequality. Theory, Culture \& Society, 26(6), pp. 206-233, 2009. https:// doi.org/10.1177/0263276409352194

[34] Schweickart, D., After Capitalism, 2nd edn., Rowman \& Littlefield Publishers: Lanham, 2011.

[35] Ghista, D.N., Socio-Economic Democracy and the World Government: Collective Capitalism, Depovertization, Human Rights, Template for Sustainable Peace, World Scientific Publishing: Singapore, 2014.

[36] Raco, M., Competition, collaboration and the new industrial districts: Examining the institutional turn in local economic development. Urban Studies, 36(5-6), pp. 951-968, 1999. https://doi.org/10.1080/0042098993295

[37] Widestrom, A., Displacing Democracy: Economic Segregation in America, University of Pennsylvania Press: Philadelphia, 2015.

[38] Chuang, M.-Y., Chen, C.-J. \& Lin, M.-J., The impact of social capital on competitive advantage: The mediating effects of collective learning and absorptive capacity. Management Decision, 54(6), pp. 1443-1463, 2016. https://doi.org/10.1108/md-11-2015-0485

[39] Hana, U., Competitive advantage achievement through innovation and knowledge. Journal of Competitiveness, 5(1), pp. 82-96, 2013. https://doi.org/10.7441/joc.2013.01.06

[40] MacKinnon, D., Cumbers, A. \& Chapman, K., Learning, innovation and regional development: a critical appraisal of recent debates. Progress in Human Geography, 26(3), pp. 293-311, 2002. https://doi.org/10.1191/0309132502ph371ra

[41] Baltazar Herrera, M.E., Creating competitive advantage by institutionalizing corporate social innovation. Journal of Business Research, 68(7), pp. 1468-1474, 2015. https:// doi.org/10.1016/j.jbusres.2015.01.036

[42] Betcherman, G., McMullen, K. \& Davidman, K., Training for the New Economy: A Synthesis Report, Canadian Policy Research Networks: Ottawa, 1998.

[43] Kelly, K., New Rules for the New Economy: 10 Radical Strategies for a Connected World, Penguin Books: New York, 1999. 
[44] Cortright, J., New growth theory, technology and learning: A practitioners guide. Reviews of Economic Development Literature and Practice, 4, pp. 1-35, 2001.

[45] Foray, D. \& Lundvall, B., The knowledge-based economy: from the economics of knowledge to the learning economy. In Employment and Growth in the KnowledgeBased Economy, ed. OECD, OECD Documents: Paris, pp. 11-34, 1996.

[46] Hidalgo, A. \& Albors, J., Innovation management techniques and tools: A review from theory and practice. $R \& D$ Management, 38(2), pp. 113-127, 2008. https://doi. org/10.1111/j.1467-9310.2008.00503.x

[47] Sorenson, O., Rivkin, J.W. \& Fleming, L., Complexity, networks and knowledge flow. Research Policy, 35(7), pp. 994-1017, 2006. https://doi.org/10.1016/j.respol.2006.05.002

[48] Arnstein, S.R., A ladder of citizen participation. Journal of the American Planning Association, 35(4), pp. 216-224, 1969.

[49] Fagerberg, J. \& Verspagen, B., Technology-gaps, innovation-diffusion and transformation: An evolutionary interpretation. Research Policy, 31(8-9), pp. 1291-1304, 2002. https://doi.org/10.1016/s0048-7333(02)00064-1

[50] Röger, W., Structural changes and new economy in the EU and the US. In The New Economy and Economic Growth in Europe and the US, eds. D.B. Audretsch \& P.J.J. Welfens, Springer-Verlag: Berlin, Heidelberg and New York, pp. 7-27, 2002.

[51] Takaki, L., Employee ownership+accountability=competitive advantage: Precor drives organizational change. Industrial and Commercial Training, 37(3), pp. 145-149, 2005. https://doi.org/10.1108/00197850510593755

[52] Royer, S., Waterhouse, J., Brown, K. \& Festing, M., Employee voice and strategic competitive advantage in international modern public corporations - An economic perspective. European Management Journal, 26(4), pp. 234-246, 2008. https://doi.org/10.1016/j.emj.2008.03.002

[53] Bannister, D.R., Making employee ownership a competitive advantage. Management Review, p. 46, 1995.

[54] Thompson, P., Mcwilliams, A. \& Shanley, M., Creating competitive advantage: A stakeholder view of employee ownership. International Journal of Strategic Change Management, 5(3), pp. 262-278, 2014. https://doi.org/10.1504/ijscm.2014.064468

[55] Schumpeter, J.A., The Theory of Economic Development: An Inquiry into Profits, Capital, Credit, Interest, and the Business Cycle, Transaction Publishers: New Jersey, NJ, 1934.

[56] Cooke, P. \& Wills, D., Small firms, social capital and the enhancement of business performance through innovation programmes. Small Bus Eco, 13, pp. 219-234, 1999.

[57] McElroy, M.W., Second generation knowledge management, 2002. Retrieved from http://www.macroinnovation.com/images/McElroy_On_2ndGenKM.pdf

[58] Cooke, P., Introduction: Origins of the concept. In Regional Innovation Systems: The Role of Governance in a Globalised World, eds. H.J. Braczyk, P. Cooke \& M. Heidenreich, UCL Press: London, pp. 2-27, 1998.

[59] Weaver, P., Jansen, L., van Grootveld, G., van Spiegel, E. \& Vergragt, P., Sustainable Technology Development, Routledge: New York, 2017.

[60] Lavie, D., The competitive advantage of interconnected firms: An extension of the resource-based view. Academy of Management Review, 31(3), pp. 638-658, 2006. https:// doi.org/10.5465/amr.2006.21318922

[61] Kitschelt, H., Lange, P., Marks, G. \& Stephens, J.D. (eds), Continuity and Change in Contemporary Capitalism, Cambridge University Press: New York, 1999. 
[62] Allard, S.W., Place, race, and access to the safety net. In The Colors of Poverty: Why Racial and Ethnic Disparities Persist, eds. A.C. Lin \& D.R. Harris, Russell Sage Foundation: New York, pp. 232-260, 2008.

[63] Johnson, O.C.A., Inclusion, exclusion, and the "new" economic inequality. Texas Law Review, 94, pp. 1647-1665, 2016.

[64] Sharkey, P., The intergenerational transmission of context. American Journal of Sociology, 113(4), pp. 931-969, 2008. https://doi.org/10.1086/522804

[65] Barca, F., McCann, P. \& Rodríguez-Pose, A., The case for regional development intervention: Place-based versus place-neutral approaches. Journal of Regional Science, 52(1), pp. 134-152, 2012. https://doi.org/10.1111/j.1467-9787.2011.00756.x

[66] Bynner, C., Rationales for Place-Based Approaches in Scotland. What Works Scotland, 2016. Available at http://eprints.gla.ac.uk/120913/7/120913.pdf (16 December, 2017).

[67] Pinoncely, V., Poverty, Place and Inequality: Why Place-Based Approaches Are Key to Tackling Poverty and Inequality, Royal Town Planning Institute: London, 2016.

[68] Tomaney, J., Place-Based Approaches to Regional Development: Global Trends and Australian Implications, Australian Business Foundation Limited: Sydney, 2010.

[69] Reed, R., Storrud-Barnes, S. \& Jessup, L., How open innovation affects the drivers of competitive advantage: Trading the benefits of IP creation and ownership for free invention. Management Decision, 50(1), pp. 58-73, 2012. https://doi. org/10.1108/00251741211194877

[70] Chesbrough, H., Open innovation: A new paradigm for understanding industrial innovation. In Open Innovation: Researching a New Paradigm, eds. H. Chesbrough, W. Vanhaverbeke \& J. West, Oxford University Press: New York, pp. 1-12, 2006.

[71] Loh, P. \& Jimenez, S., Solidarity Rising in Massachusetts: How Solidarity Economy Movement Is Emerging in Lower-Income Communities of Color, Solidarity Economy Initiative: Cambridge, 2017.

[72] Edvinson, L. \& Malone, M., Intellectual Capital, Harper Business: New York, 1997.

[73] Dahl, R.A., A Preface to Economic Democracy, University of California Press: Berkeley, 1985.

[74] Ganz, M., Public narrative, collective action, and power. In Accountability through Public Opinion: From Inertia to Public Action, eds. S. Odugbemi \& T. Lee, The World Bank: Washington, D.C, pp. 273-289, 2011.

[75] Porter, M.E. \& Kramer, M.R., Strategy and society: The link between competitive advantage and corporate social responsibility. Harvard Business Review, pp. 80-92, 2006.

[76] McWilliams, A. \& Siegel, D.S., Creating and capturing value: Strategic corporate social responsibility, resource-based theory, and sustainable competitive advantage. Journal of Management, 37(5), pp. 1480-1495, 2011. https://doi.org/10.1177/0149206310385696

[77] Barber, B.R., If Mayors Ruled the World: Dysfunctional Nations, Rising Cities, Yale University Press: New Haven and London, 2013.

[78] Marquetti, A., Schonerwald da Silva, C.E. \& Campbell, A., Participatory economic democracyinaction:ParticipatorybudgetinginPortoAlegre, 1989-2004.ReviewofRadical Political Economics, 44(1), pp. 62-81. https://doi.org/10.1177/0486613411418055

[79] Bevilacqua, C., Politiche di Sviluppo e Pianificazione Territoriale: Tra Innovazione e Prassi Ordinaria, Gangemi Editore. (in Italian): Roma, 2001. 